Progress in Human Geography, forthcoming [Final copy January 2006]

\title{
Notes towards autonomous geographies: creation, resistance and self management as survival tactics
}

Jenny Pickerill* and Paul Chatterton**

* Jenny Pickerill, Department of Geography, Leicester University, University Road, Leicester, LE1 7RH. 0116252 3836, j.pickerill@leicester.ac.uk

** Paul Chatterton, Department of Geography, Leeds University, University Road, Leeds, LS2 9JT. 01133436636 , p.chatterton@leeds.ac.uk

\begin{abstract}
This paper's focus is what we call 'autonomous geographies' - spaces where there is a desire to constitute non-capitalist, collective forms of politics, identity and citizenship. These are created through a combination of resistance and creation, and a questioning and challenging of dominant laws and social norms. The concept of autonomy permits a better understanding of activists' aims, practices and achievements in alter-globalisation movements. We explore how autonomous geographies are multi-scalar strategies that weave together spaces and times, constituting in-between and overlapping spaces, blending resistance and creation, and combining theory and practice. We flesh out two examples of how autonomous geographies are made through collective decision-making and autonomous social centres. Autonomous geographies provide a useful toolkit for understanding how spectacular protest and everyday life are combined to brew workable alternatives to life beyond capitalism.
\end{abstract}

\section{Key words}

Autonomy, everyday life, activism, alternative spaces, resistance, creation, interstitial, localization

\section{Introduction}

This paper is about what we call 'autonomous geographies' - those spaces where people desire to constitute non-capitalist, egalitarian and solidaristic forms of political, social, and economic organisation through a combination of resistance and creation. Inspired by groups such as the Mexican Zapatistas, the concept of autonomy is being increasingly employed by anti-capitalist activists such as the Wombles, Disobidientis and Dissent! to structure and articulate their practices and aims. At the same time, a reinvigoration and reinterpretation of autonomist Marxism has provided a pathway towards a more socially just society (Cleaver, 1979; Hardt and Negri, 2000, 2005; Katsiaficas, 1997; Wright, 2002).

We have coined the term 'autonomous geographies' as part of a substantive and linguistic intervention, responding to multiple crises. We make no excuses for this; calling forth autonomy does not simply lead to concrete solutions to change the world. Nor is the term a panacea; to offer it as such would sustain the problems of blueprints which plague the contemporary world. However, autonomous geographies are part of a vocabulary of urgency, hope and inspiration, a call to action that we can 
dismantle wage labour, the oil economy, or representative democracy, and that thousands of capable and workable micro-examples exist. A focus on autonomy is simultaneously a documentation of where we are, and a projection of where we could be. As a narrative of realism and idealism, this paper -- and our research -- is an attempt to document radical and workable 'futures in the present' (Cleaver, 1993) and to find escape routes out of this capitalist existence (Gibson-Graham, 1996).

The paper's objectives are threefold. First in order to understand autonomy's importance, we need to explore its usage, meanings and widespread practices in activists' everyday activities. Second, we discuss how autonomy can facilitate a more nuanced understanding of anti-capitalist movements. Finally, a politics of hope infuses this paper; making autonomous geographies comprises important moments of resistance. Autonomous practices have already resulted in real changes for some participants, for example social centres' provision of space and food, and survival strategies in Argentina (Chatterton, 2005). Beyond examples of success, we look further than constrained pragmatic visions and "interrupt space and time ... to open up perspectives on what might be" (Pinder, 2002, p.229).

Our focus on autonomy is an attempt to clarify what can seem a diffuse concept, and a way to explore the materialisation of utopian visions. First, autonomy has become one of the hallmarks of varied activism, forming part of the alter-globalisation movement which seeks to challenge, disrupt, and re-imagine our understandings of political, economic and cultural processes (Featherstone, 2003). Alter-globalisation is the preferred term as it emphasizes anti-capitalist and social justice movements' creativity, celebrating the movement's transnationality and their solidarity networks. This multi-scalar and multi-faceted activism manifests itself through global and regional convergences (such as People's Global Action meetings or large-scale demonstrations coinciding with ministerial meetings of the G8, the World Trade Organisation or the European Union), through localised autonomous spaces and alternative processes (such as social centres, eco-villages, alternative currencies, food production, housing co-operatives and self education), and experiments in non hierarchical organisation and consensus-based decision-making. Most importantly, we explore the role of everyday practices in these movements' constitution, as they work alongside -- indeed comprise vital building blocks for - mass protests.

Second, a growing critique of movements' failure to suggest, or indeed deliver, workable alternatives stems from autonomous activists' reluctance to build permanent organisations, formulate strategies, or adopt traditional representative structures. Hence, the mainstream media often treat them inaccurately, seeking the familiarity of spokespeople, manifestos and organisational coherence. Some scholars have also critiqued their localisation, arguing that local responses are inadequate to challenge globalisation (Bauman, 2002; Cameron and Palan, 2004; Peck and Tickell, 2002). To clarify, we propose to use the concept of autonomous geographies to understand alter-globalisation movements as a progressive politics, not grounded through a particular spatial strategy but as a relational and contextual entity drawing together resistance, creation and solidarity across multiple times and places.

We begin by defining autonomy. First, autonomy is a contextual and situated tendency which has many trajectories. We are concerned with movements that seek freedom and connection beyond nation-states, international financial institutions, global corporations and neoliberalism - what we might otherwise call global anticapitalism. Second, autonomy is a socio-spatial strategy, in which complex networks 
and relations are woven between many autonomous projects across time and space, with potential for translocal solidarity networks. Third, the interstitial nature of autonomy means the lack of an 'out there' from which to build autonomy, hence creating a constant interplay between autonomy and non-autonomy tendencies. Fourth, autonomy is resistance and creation, a tendency that proposes but also refuses. Finally autonomy is praxis, a commitment to the revolution of the everyday. A necessary rejection of routes to power means a faith in collective process, nonhierarchical decision-making and mutual aid. In the second part of the paper, we look at how autonomy is made and re-made by activists in two examples (decisionmaking structures at a recent convergence space; autonomous social centres). We conclude by considering the power and limitations of autonomy and ask to what extent can autonomous geographies challenge everyday realities of capitalist ways of organising society?'

The inspiration for this piece has been personal, political and academic (Chatterton, 2002, Chatterton and Hollands 2003, Gordon and Chatterton 2004, Chatterton, 2005; Pickerill, 2003a, 2003b and 2004). A strong body of geographical work has sought to be socially relevant and pursue participatory and ethical approaches, often beyond the academy (Blomley, 1994; Pain, 2003; Cloke, 2002; Kitchen and Hubbard, 1999). We are closely embedded in a number of activist groups (in particular a social centre in Leeds called The Common Place, Dissent! a network of Resistance against the G8, as well as an ecological land project, and a housing co-operative), which represent these difficult moments of negotiating between tendencies towards autonomy and non-autonomy (or heteronomy). Hence, we are unashamedly commentators on -- and also embedded participants within -- autonomous projects. Our encounters are as academic-activists, undertaking embedded or participatory forms of action research which are empathic and interactive rather than extractive and objective (see Pain, 2003). This contact, however, does not blind us to activism's limitations; in fact some of the strongest critiques have emerged from within such movements. ${ }^{1}$

\section{Defining autonomy}

The word 'autonomous' comes from the Greek autos-nomos, meaning 'selflegislation'. It shares many similarities with anarchism, meaning 'without government'. Together they combine to make a powerful toolkit for social and environmental justice politics (see Bookchin, 1996; Cook and Pepper, 1990; Blunt and Wills, 2000; Kumar, 1987; Sheehan, 2003; Berkmann, 2003; Joll, 1979; Marshall, 1992). In this section, we examine autonomy in five main ways: as a concept comprising different tendencies and trajectories; as a temporal-spatial

$1 \quad$ Anderson (2004) rightly notes that a specific activist identity is enacted during environmental direct action, an identity which sets the activist-self apart from normal society through particular spatial practices, moral codes and politico-cultural preferences. Collective identity is normally strengthened through bonds of trust, loyalty and affection, as well as antipathy to non-members (Goodwin, Jasper and Polletta, 2001). While an 'activist mentality' sets activists apart as specialists in social change, the concept of 'activist' and their 'other' is far from simple as those involved in autonomous projects represent highly mobile, multilayered and contradictory identities. Hence, the large grey area between the ontological extremes of activist and public suggests that the position of 'non-activist' excludes and marginalises a large majority (Halfacree, 2004), many of whom would be sympathetic to autonomous projects' practices and politics. These more hybrid, contingent notions of self are used here. 
strategy between and beyond the 'global versus local' axis; as a form of interstitial politics; as a process of resistance and creation; and as a coherent attempt at praxis with its strong sense of pre-figurative politics and commitment to the revolution of the everyday.

\section{Autonomies: tendencies and trajectories}

Autonomy is moveable, historically specific, highly contextual and contested and used to pursue a variety of ends and ideologies (Brown, 1992). It has been variably used within traditions of autonomous Marxism, social anarchism, anarchosyndicalism, regional separatism, national socialism, anarcho-primitivism, Zapatismo, ecologism and anti-capitalism. Such flexibility in usage and interpretation makes it a dangerously fuzzy concept. Autonomy can better understood by considering these tensions in depth, and making a claim for the validity and normative worth of certain tendencies over others.

The individual-collective dichotomy is a key tension. In the first case, autonomy can be seen as the free-floating disconnected individual with highly egoistic desires, tendencies enshrined in classic, eighteenth century liberalism and based upon nation-states' sovereign rights and market interactions between rational, autonomous and self-interested individuals. Such individual autonomy is prominent in modern-day consumer societies, where autonomy is stripped down to consumer choice or the practices and discourses of highly individualised capitalist entrepreneurs whose aims are to reduce government legislations in order to make money (see Ruggie, 2004). Unrestrained capitalism, then, is itself a quest for autonomy. However in the second case, autonomy is a collective project, fulfilled only through reciprocal and mutually agreed relations with others. Ideas of collectivism and mutuality are key, emerging as strong currents in nineteenth century anarchist notions through thinkers such as Peter Kropotkin (1987) who sought to prove that the dominant tendency in human relations was co-operation not competition, and Pierre Joseph Proudhon and Michel Bakunin who envisaged autonomous individuals living freely and trading within a federation of communities (Marshall, 1992; Joll, 1979).

Some of the concrete differences in usages and contexts are worth expanding upon. First, the project of autonomy as self-rule is not simply the terrain of confrontational or utopian politics. Various causes have enlisted it to renew participation in market democracies, where it is also associated with devolution or subsidiarity where the individual or the local/regional level seeks greater power from the bureaucratic centre (Clark, 1984; Wolman and Goldsmith, 1990). More co-operative versions of capitalism -- Thrift's 'soft capitalism' (1998) -- attempt to re-embed the market into community structures and make corporations more accountable to civil society. Hence, ideas of localism, self-management, the co-operative or solidarity/economy, sustainable communities, devolution and autonomy have found their way into mainstream government and community policy debates (in the UK see for example the Future Foundation Group, the New Economics Foundation, and DEMOS).

More worryingly, autonomy is often asserted in reinvigorating nationalisms (Rupert, 2003). Separatist, insurrectionary and fundamentalist groups may lay claim to autonomy as a means of gaining absolute control over territory, resources and populations, often using violence. Such groups include terrorist networks, Islamic fundamentalist groups such as Hamas or Western proto-revolutionary groups such as the Weather Underground, Symbionese Liberation Army, Bader Meinhoff in Germany and the Angry Brigade in the UK. The contemporary USA also sees a far- 
right anti-state tendency that seeks to assert its autonomy through non-payment of taxes.

Moreover, there are varying definitions of autonomy from within the varied alterglobalisation movement, including non governmental organizations (NGOs), direct action, peace and anti-fascist groups, Trotskyite parties and organisations such as Workers Power and Globalise Resistance, as well as by national-socialist governments such as Chavez's Venezuela and universalist humanitarian movements such as the World Social Forum (Starr and Adams, 2003). While some of these groups and movements have a commitment to non-hierarchical organising, many remain embedded in organised party socialism or vertical institutional structures and hence have been criticised for their continuing use of hierarchical decision making, secrecy and closure (Sen et al., 2004).

This brings us to what we define as the core values of autonomous geographies which will inform this paper. Castoriadis' (1991) conceptualization showed that the autonomy project's individual and collective aspects are highly inter-related, when it is regarded as a project of the renewal of democracy. Individual autonomy implies individuals' capacity to make choices in freedom, while collective autonomy implies a given society's or group's self-rule through the freedom of its institutions and equal participation in institutions. These inter-relations are vital. As de Souza (2000: 189) notes, 'strong individual autonomy in a proper sense will be a fiction ... in a society which is characterized by structural asymmetry in the distribution of power'. Castoriadis rightly understood that the individual would never be free within the confines of capitalism, authoritarian socialism or representative democracy. This project of simultaneous collective and individual autonomy as a tool for renewing democracy is defined through personal freedom, a mistrust of power and a rejection of hierarchy, and the advocacy of self-management, decentralised and voluntary organisation, direct action and radical change.

Several groups define these tendencies, many taking their cue from Italian autonomism and the autonomous Marxism tradition. Groups such as Autonomia Operaio (Workers Autonomy), Potere Operaio (Worker's Power) and Lotta Continua (The Struggle Continues) extended the struggle from the factory to the wider city, focusing on community and working class struggles and helping to spark countless strikes, factory occupations, sabotages and squats (Lotinger and Marazzi, 1980; Wright, 2002). The movement of 1977 was the apogee of Italian autonomy, promoting experiments in class confrontation such as squatting, looting and pirate radio. The Situationist International -- along with a range of other groups involved in the May 1968 uprisings -- provide a key backdrop for today's autonomous struggles. The Situationists demanded that an insurrectionary imagination be brought into everyday life, challenging the contradictions which shape society and replacing it with a sense of a possible immediate revolution (for example Vaneigem, 1979).

Today's alter-globalisation activists continue this tradition, by combining attacks on corporate globalisation with proposals for everyday alternatives (for example Schalit, 2002; Duffuor and Bové, 2001; Cockburn and St Clair, 2000; Callinicos, 2003; Houtart and Polet, 2001; Kingsnorth, 2003). Many groups have taken on an explicit autonomy agenda to maintain a non-aligned and confrontational attitude and distance themselves from reformist elements in the anti-capitalist movement. As a result, direct democracy and spokecouncils are widespread tools in today's peace, ecological and anarchist movements. Self-management and voluntary organisation is 
central within the housing co-operative and eco-village movement. Urban social centres have taken on issues of gentrification and privatization, while ecological direct activists and summit siege activists at Seattle, Genoa and Cancun have shown the validity and successes of civil disobedience. We can also point to the Wombles (White Overall Movement Building Libertarian Effective Struggles) in the UK and the Disobidienti in Italy, while groups like Earth First! highlight the need to confront industrial capitalism directly. The most inspiring autonomy project versions come from struggles in the majority world, best captured by Argentina's Piqueteros, and the Zapatistas in Chiapas state, Mexico. In the latter, autonomous municipalities and direct democracy have been established, along with an autonomous infrastructure of health, education and production. Zapatista self-rule is distinguished by a commitment to openness, full participation and desire for others to experiment, without making exclusive claims on the governance of the Mexican nation-state.

To specify our conceptualization then, we agree with Carmen's (1996) suggestion that autonomy rests on four pillars: political ownership and control; cultural and media literacy; the self-determination of organizational forms; and economic self-reliance. Katsiaficas (1997) goes further by outlining several principles which have defined European autonomous movements: collectivism; independence from political parties, trade unions and capital circulation; popular power, self-determination and decentralised direct democracy; consensus-based decision-making (or horizontality); diversity and pluralism; the revolution of the everyday; internationalism; and conscious spontaneity, militancy and confrontation as tactics. This freedom with connection -- confrontation with proposition - is key, the core principle informing autonomous geographies.

\section{Autonomy as a temporal-spatial strategy: between and beyond globalisation- localisation}

To understand the quest for autonomy, there needs to be a more nuanced understanding of what activists are seeking to attain in relation to globalisation (especially corporate globalization). As well as a material reality, globalisation is a narrative, a mediated discourse constructed from multiple stories (Gibson-Graham, 1996), which is attractive due to its appearance as a plausible explanation and a clear image of the future, where globalisation is inexorable and the only option for action is to adapt and react to it. Thus the theories of globalisation are understood as 'common sense'. Moreover, the 'labour of representation' (Bourdieu, 1991, p.243) "through constant repetition in daily practice, serve[s] to reinforce narratives of 'normal' globalization" (Cameron and Palan, 2004, p.85) at the everyday level. Mundane acts, such as "using credit cards, accessing the Internet, investing in stock markets, buying 'global' branded products, consuming global 'lifestyles' ... ultimately produce the 'reality' of globalisation itself" (ibid, p.86).

However, there are always counter narratives (Escobar, 2001). By acknowledging the discursive construction of economic neoliberal globalisation, an instability appears that permits the construction of alternative narratives. By recognising that actions serve to constitute globalisation's 'reality', we can begin to challenge globalisation through changing everyday practices. Autonomous geographies are part of the constitution of other realities, creating what Harvey terms 'spaces of hope' which can lead to creative futures:

There is a time and place in the ceaseless human endeavour to change the world, when alternative visions, no matter how 
fantastic, provide the grist for shaping powerful political forces for change. I believe we are precisely at such a moment. (Harvey, 2001, p.195)

As Castells (1983) argues, through such interventions we become 'auteurs' of our own geographies; these are Lefebvre's representational, or directly lived, spaces. The struggle to represent and promote these popular histories is nothing new. Hence, autonomy is a temporal strategy - a struggle against amnesia, of not forgetting the successes and failures of past struggles (Featherstone, 2005). Collecting, preserving and talking about collective memories of previous struggles across times and spaces is the lifeblood of autonomy, providing socio-spatial reference points for projecting autonomous visions into the present and future.

Many autonomous campaigns are grounded in particular places and (re)localisation is a strong thread of such struggles (Schumacher, 1972; Douthwaite, 1996; Hines, 2000; Mander and Goldsmith; 1996). For many groups, especially those in the global south, the harsh realities of neoliberal economies are strong justifications for a placebounded, and often exclusionary, desire for self-rule and legislation (Escobar, 1995, Reynolds, 1989, Yunupingu, 1997). When the current phase of capitalist growth is predicated on dispossessing people, often by force, from control over previously unexploited resources (Harvey 2003), autonomy concerns reclaiming land and dignity for survival, identity, and history-making.

Participants in autonomous place politics are acutely aware of the local's limitations as an arena for struggle. Whether in terms of a misplaced nostalgia for 'nationalist' capitalism or a 'community' (Bauman, 2002), being separated from the wider world can equate to being marginalised as outsiders, being viewed as disengaged, unrealistic or naïve, and as leaving capitalism unchanged and unchallenged. However, autonomous projects are never just of the here and now. Featherstone (2005) discusses how local militant particularisms are not simply locally-bounded and then networked globally, but from the start are a product of mobile trans-national, or extra-local, geographies of resistance and solidarity. To suggest that resistance is either local or global closes us to the creative interconnections that fuels resistance movements, being facilitated through numerous flows (speaker tours, visits and exchanges between activists, conferences, meetings and convergence gatherings, or information from the internet, zines and magazines). Gatherings and convergence spaces (Routledge, 2003) are used explicitly to allow individual and group networking to share and build ideas and tactics. Autonomous practices are not discrete localities, but networked and connected spaces, part of broader transnational network, where extra-local connections are vital social building blocks. Escobar (2001) terms such practices "multi-scale, network-orientated strategies of localization" (p.139) and the "supra-place effects of place-based politics" (p.142). Through autonomous action we can forge new identities, which can rebuild solidarities and teach about the multiscalar workings of economic globalisation. For example, squatting a building leads to a greater awareness of national-global property speculation or how the state marshals footloose investment, while a local campaign against school closure can unravel global agreements on privatisation and tradable services. Locally-grounded autonomous projects allow an unpacking of the power working at different levels through governments, corporations and local elites, and the building of extra-local solidarity and resistance. 
In this respect, an autonomous politics of place is not a mere privileging or protecting of the local as authors such as Escobar (2001) sometimes suggest. As Massey (2004a) comments, developing a nuanced 'geography of responsibility' requires a more complex, negotiated sense of place, moving away from a sense of a fixed globality (Dirlik, 2000) or locality, towards an appreciation of the countless times and spaces which are the building blocks of both. Overcoming the over-simplified globalbad, local-good dichotomy means appreciating that while some local places are vulnerable and worth protecting, others are powerful and inflict harm. Hence, some places, processes and flows need to be de-legitimised, countered and reduced, while others are re-legitimised and promoted. Following Massey (2004b), a politics of autonomous geographies does not concern linear progression towards some desired place-bound utopia or equilibrium, but an obligation to recognise co-existence, negotiations and conflict. Autonomous geographies are 'entanglements and configurations of multiple trajectories, multiple histories' (Massey, 2004b, 148).

Yet it is more than a sense of multiplicity or negotiation. Autonomous geographies entail both conflict and proposition, and clearly these occur in every place. Swyngedouw's (1997) discussion of 'glocalisation' suggests practices of resistance are orientated around networks of global solidarity. The use of the internet, prevalent in alter-globalisation movements, serves to reinforce the connectivity and 'crossappropriation' of placed-based practices (Pickerill, 2003b):

It is no longer the case, as neoliberal globalizers would have it, that one can only contest dispossession and argue for equality from the perspective of inclusion into the dominant culture and economy. In fact, the opposite is becoming the case: the position of difference and autonomy is becoming valid, if not more, for this contestation. (Escobar 2001 p.169)

Autonomous geographies are part of a web of stories and lessons across the world and other periods of history, inspiring people to act for themselves in their locality. Participants are active in extra-local networks through solidarity with globallydistributed groups through actions, fundraising, awareness raising, information- and skill-sharing, or through virtual organising networks, which facilitate extra-local communication.

\section{Autonomy and interstitiality}

Autonomous spaces are an incomplete terrain where daily struggles are made and remade, both symbolically and materially, and where people live by their beliefs and face contradictions from living between worlds - the actually existing and the hoped for. Activists, "in their day-to-day activism show a pragmatism and a reflexivity of purpose as to what is feasible" (Purkis, 1996, 212). Although autonomy by necessity occurs in a locality, it is not the transformation of the locality which is of paramount importance, but the tendency towards autonomy which has the potential for multiscalar change. DeFilippis (2004) notes that:

we need to understand autonomy as a form of power and that autonomy is therefore a relational construct ... autonomy is not a discrete commodity that is possessed or not possessed, by individuals or localities. Instead autonomy is a set of power relations (p.29 and p.24) 
If autonomy is a 'set of power relations', a relational tendency rather than a possession, then there no clear boundaries between autonomous and nonautonomous processes and space exist. Rather there is a constant negotiation between competing tendencies towards autonomy and non-autonomy (or heteronomy). Autonomy is necessarily an emergent, and in many cases residual, property within -- and often against -- a dominant order, a desire rather than an existing state of being.

Thus there is no 'out there' external to capital relations from which to build an autonomous politics. New worlds are constantly built in the ashes of the old, although the conditions for facilitating this building constantly change. Mann (1986) refers to these as 'interstitial locations' where new forms are constituted, experienced and practised. Autonomous projects' realpolitik is their existance in a global capitalist economy where profit, a wage economy and the corporate control of goods and services prevail. Hence, the tendency for autonomy is always contested and fractured, contradictory and overlapping. On a practical level, there are constant and multiple negotiations between those seeking autonomy and their interactions with the family, workplace, consumer society, institutions and the state that impose a series of compromises. These negotiations are manifest in everyday 'realities' such as paying rent, finding work, negotiating the benefits system and government legislation, to depending on corporate controlled goods, services and information, or being monitored and surveyed. For many people, such boundaries create a sense of living between worlds: the one they are struggling against and the one they are trying to achieve.

Moreover, the peaks and troughs between periods of intense activity during demonstrations/actions and more mundane movement-building locally also create a sense of in-betweenness, unreality and disorientation. During periods of latency, solidarities, identities and communities are formed and sustained through submerged networks (Tarrow, 1998; Melucci, 1996). In these spaces of latency, activists translate ideas into action. While they have to engage with wider politics to realize their goals, they also recognise the "importance of acting for the present" (Melucci, 1996, p.213). The affirmation of ideas combined with action (or praxis) of prefigurative politics, permits autonomous groups to make "the future begin" (Jordan, 2002, p.74), through an embedding of micro-political tactics (de Certeau, 1988; Creswell, 1996; Pile and Keith, 1997, Sharp et al, 2000).

\section{Resistance and creation}

Central to autonomy is an explosive combination of making protest part of everyday life, but also making life into workable alternatives for a wider social good. Autonomous geographies are thus about exploring the practicalities of multi-scalar influence - of building a broader oppositional politics through multiple strategies beginning by enacting change in everyday lives. In practice a fusion of moments of protest, intensity and transgression (such as attending summit mobilisations, the subterranean networks and collective actions of protest camps, squatting buildings, occupying workplaces, or blocking roads) with more mundane activities (such as facilitating meetings, skills sharing, communal cooking, collective education, or running a local food co-operative) occurs. Autonomy projects destroy and propose, resist and create. Refusing an 'instituted social heteronomy' - the institutions, norms and laws from distant others (religion, the family, or the state) which limit autonomy (Castoriadis, 1991: 150), refusals become an act of creation, evoking different forms of power. Hardt and Negri (2000) talk about the tactics of desertion, exodus and 
nomadism, where we turn our backs on institutionalized power and build counterpowers from our own resources.

Peak moments of resistance rest upon the often hidden but vital support structures where resistance is defined and planned, and everyday alternatives are put into practice. Autonomous convergence spaces created at recent summit events for activists to meet, plan resistance and create exemplify this, such as in mobilisations against the G8 summits in Evian (France, 2003) and Gleneagles (Scotland, 2005). Here autonomous neighbourhoods were created temporarily as a living alternative to capitalism (providing cheap food and accommodation, alternative technology, collective decision-making, site security and free communications and information access), and as spaces to plan resistance.

\section{Praxis and the revolution of everyday life}

In essence, autonomy is a coming together of theory and practice, or praxis. Hence, it is not solely an intellectual tool nor a guide for living; it is a means and an end. Autonomous geographies represent the deed and the word, based around ongoing examples and experiments. Autonomous spaces are not spaces of deference to higher organisational levels such as non-governmental organisations, political representatives or trade union officials. They are based around a belief that the process is as important as the outcome of resistance, that the journey is an end in itself. As the Zapatistas say: 'we don't know how long we have to walk this path or if we will ever arrive, but at least it is the path we have chosen to take'. Autonomous geographies are based around a belief in prefigurative politics (summed up by the phrase 'be the change you want to see'), that change is possible through an accumulation of small changes, providing much needed hope against a feeling of powerlessness. Part of this is the belief in 'Doing It Yourself' (see McKay, 1998) or creating workable alternatives outside the state. Many examples have flourished embracing ecological direct action, free parties and the rave scene, squatting and social centres, and open-source software and independent media (Plows 2002; Seel et al., 2000; Wall, 1999; Chatterton and Hollands, 2003; Pickerill, 2003a, forthcoming). Resources are creatively re-used, skills shared, and popular or participatory education techniques deployed, aiming to develop a critical consciousness, political and media literacy and clear ethical judgements (Friere, 1979).

In the terrain opened up by the failure of state-based and 'actually existing socialism', autonomy allows a rethinking of the idea of revolution - not about seizing the state's power but, as Holloway (2002) argues, 'changing the world without taking power' (Vaneigem, 1979). Autonomy does not mean an absence of structure or order, but the rejection of a government that demands obedience (Castoriadis, 1991). Examples of post-capitalist ways of living are already part of the present (GibsonGraham, 1996). The documentation of the 'future in the present' has been a hallmark of work by anarchist, libertarian and radical scholars from Peter Kropotkin (1972) to Colin Ward (1989) and Murray Bookchin (1996). Their work looks for tendencies that counter competition and conflict, providing alternative paths. Some of these disappear, others survive, but the challenge remains to find them, encourage people to articulate, expand and connect them.

Autonomous projects face the accusation that even if they do improve participants' quality of living, they fail to have a transformative impact on the broader locality and even less on the global capitalist system (DeFilippis, 2004). Consequently, in talking 
of local resistance, Peck and Tickell (2002) suggest, "the defeat (or failure) of local neoliberalisms - even strategically important ones - will not be enough to topple what we are still perhaps justified in calling 'the system"' (p.401). However, commentators make the mistake of looking for signs of emerging organisational coherence, political leaders and a common programme that bids for state power, when the rules of engagement have changed. A plurality of voices is reframing the debate, changing the nature and boundaries of what is taken as commonsense and creating workable solutions to erode the workings of market-based economies in a host of, as yet, unknown ways. Rebecca Solnit's writings on hope remind us that while our actions' effects are difficult to calculate, "causes and effects assume history marches forward, but history is not an army. It is a crab scuttling sideways, a drip of soft water wearing away stone" (2004: 4).

The wider effects of autonomous spaces and movements on localities' culture, politics and spatiality are difficult to gauge and to a large extent unknowable. Reflecting on socialist and national governments' abuses of power, many autonomous groups are reluctant to use projects to create a counter-power bloc, which can literally 'take on' corporate and state power. As Holloway (2002) notes, taking over state power simply reproduces that power, albeit with different leaders, and the ability to have 'power over' other groups. More than a reluctance to take power, autonomy is a commitment to freedom, non-hierarchy and connection and a desire to eliminate (or reduce) power relations. Connections across local and transnational, creative networks of solidarity generate a feeling of being powerful and not condemned to neoliberalism (Cumbers and Routledge, 2004: 819).

Increasingly global networks for freedom and solidarity form an incomplete and plural version of the future, where autonomous visions link up multiple locations and become generalisable across space without recreating the burden and violence of powerful organisations. Using the concept of autonomous geographies to analyse alter-globalisation movements' aims and processes permits an exploration how these networks deal with power. The necessity to rewrite the dominant narratives and shift the 'commonsense' of globalisation is, of course, no easy task, as an alternative way of life cannot be easily imagined and the power and resources to 'self-construct our own life narratives' (Lash, 1994) are lacking. Yet a wealth of examples exists, inviting others to experiment and propose.

\section{Making autonomous geographies}

In this second section, we explore two examples to begin to understand the practicalities of making autonomous geographies as examples of continuing experiments that speak of the success and problems of enacting change through autonomous practices. Crucially, their limitations do not signal outright failure, but experiences from which lessons can be drawn.

\section{Reinventing political process: direct democracy and horizontality}

The desire for autonomy is underpinned by a reinvention and reinvigoration of political process, decision-making and communication through experimentation with particular organisational principles such as direct democracy, decentralisation and consensus (Seeds for Change, 2003; Indymedia, 2003; Butler and Rothstein 1988; Starhawk, 1988). Such principles speak clearly to the hallmarks of autonomy outlined above: they are flexible tools which mutate between times and places; they are creative processes acting as building blocks for resistance; they are embedded in 
reinvented everyday social relations, encouraging participants to communicate more consensually; and they are interstitial, exist alongside other forms of political process.

The loose, ephemeral network form is key to autonomous practices (Castells, 1996, Notes from Nowhere, 2003). It has become common to think not of a single movement, but of a 'movement of movements' (Mertes, 2004), which -- lacking a centre -- makes them difficult to control, monitor and police. Such principles are flexible tools rather than dogmas, and are used to guard against the formation of hierarchies, leaders and centralisation of power. Practically, we can point to the use of affinity groups (based around the desire to take action or organise in small groups sharing common goals and areas at a human scale), spokes-councils (a federated structure of the previous groups, offering proposals and making decisions at a wider level), and consensus decision-making techniques (a rejection of decision making by majority voting, hierarchy and committee in favour of techniques for reaching decisions by consensus) as examples of this organisational framework (Pickerill, 2004). Such techniques became commonplace within resistance movements since the 1960s and are now widely used by the global grassroots network People's Global Action (PGA) and activist networks in the UK such as Rising Tide, Dissent! and Earth First!. Similarly, those involved in alternative and independent media, such as IndyMedia, have developed non-hierarchical techniques for communication (Kidd, 2003; Pickerill, forthcoming). Such techniques (like the collaborative web page 'Wikis' used by social forums) allow wide participation and discussion on visions and practical alternatives.

During the 2005 G8 summit in Gleneagles, Scotland a convergence space was formed based upon such organisational principles. Named the 'hori-zone' (horizontalzone), the space was intended to act as a living example of horizontal politics through direct democracy and without leaders, a living testimony to the feasibility of low-impact living and a place to plan and carry out confrontational politics. Developed by working groups over several months, water, roads, food, safety, welcome, energy and structures were coordinated into 'neighbourhoods', similar to the 'barrios' used as convergence spaces during the 2003 G8 summit in Evian, France. These neighbourhoods facilitated the site visitors' arrival, accommodation, feeding and orientation, helping to make connections and build affinity between individuals with few previous contacts. Each evening, the convergence space had a spokes-council, based around a 'hub and spoke' model of representatives - 'spokes' from each neighbourhood forming a hub in the centre connected to all those they represent. The spokes-council considered and made decisions on proposals through conversations with each neighbourhood's nominated 'spoke'. The spokes discussed each point through iterations with their group and then took information back to the neighbourhood for further discussion. Meetings were facilitated by the facilitator, stacker, note taker and 'vibe' watcher. Testing for consensus rather than majority voting was used for reaching decisions. Through this process, decisions involving over 1000 people were made relatively quickly and effectively.

The whole site was an organic experiment in autonomous politics, and hence faced many problems as well as successes. There were issues with the viability and attractiveness of the hori-zone. At its peak it only attracted 3,000 people, and its external appearance placed it firmly within the subcultural activists' ghetto. As a result, it was subject to negative stereotypes from the public and aggressive policing. In terms of decision-making, the participatory processes were unfamiliar and required more participant involvement than in their daily life. Hence, the day-to-day running of 
the camp often fell to a small group of people. Further, while consensus practices were deliberately aimed at removing centres of power by removing hierarchies and employing facilitators, informal hierarchies still remained. These could be gendered (for example machismo) or are reflected in ghetto lifestyles that appear exclusionary to newcomers. The micro-scales of internal power relations were also important; without well-trained facilitators, certain individuals dominated discussions and decisions. A heightened awareness of internal power relations is necessary for such spaces to run successfully.

Finally and most challenging, is the work of political theorists such as Mouffe (2005) who suggest that rather than seek consensus difference should be celebrated. Although establishing convergence spaces was an act of defiance (and a moment of antagonism) against the G8 agenda, activists sought to reach consensus within the zone. Mouffe argues such consensus is not only impossible to achieve, but politically obstructive. In other words, when done well, consensus enables activists to listen to others' views and incorporate them in groups' actions, but when done poorly seeking consensus creates extremes and can marginalize - not accommodate -- those with different views. Mouffe calls for 'agonistic pluralism' (2000) whereby political structures are able to accept that differences always occur in society and seek to "appreciate the pluralistic nature of the world" $(2005,115)$. If we create space for agonistic politics, antagonistic responses expressed in violence or terrorism are less likely. In relation to autonomous activists, "the central question of democratic politics, the question which the anti-globalization movement needs urgently to address [is] how to organize across differences so as to create a chain of equivalence among democratic struggles" $(2005,113)$. Mouffe focuses her attention on the scale of world order and concedes that consensus is at times necessary (albeit always accompanied by dissent).

Despite these problems, however, the very commitment to the process, as a utopian vision and a materialisation of a desire for something better, working through and evolving the use of direct democracy and horizontality, offers the hope of creating the future in the present. Such processes do not defer to the idea of a future revolution but neither are they confined by restrictive present ways of communicating such as mandated power and majority voting.

\section{Creating autonomous spaces: Social centres}

Our second example, autonomous social centres, illuminates the processes and practices of making autonomy: they draw upon examples of resistance and solidarity from many times and spaces. Being interstitial, they incorporate the desire for autonomy as well as the realities of compromise with the state and police. They are laboratories for resistance and creation, being ongoing forums for action and reflection or praxis. Times of radical protests have often been "where space has been reclaimed, transformed and subverted" (Begg, 2000, p.198). However, due to state repression or a desire not to be recuperated, many such place experiments are -often intentionally -- limited and ephemeral (for example Bey, 1991). Other autonomous projects aim to be more permanent, offering on-going experimentations with non-capitalist ways of organising social and economic life (Begg, 2000). Whereas earlier communes and co-operatives illustrated the negative consequences of isolation, recent spaces acknowledge the power of interaction with society. The interstitial location of these spaces between worlds is one of their key strengths, being able to survive and communicating ideas. Often difficult and marginal, spaces permit links and, however problematically, bring disparate groups together. Spain, 
Germany, the Netherlands and Italy have been home to the most dramatic growth of social centres (Ruggiero, 2000; Mudu, 2004). Since the 1960s autonomous groups have focused on the setting up social centres, usually through squatting. Social centres have become the focus of struggles over the right to hold property in common and public ownership, the right to challenge wage labour and increasing productivity and the commercialization of free time, and the decline of free or cheap services.

There is an ever changing and growing list of rented, bought and squatted social centres in the UK, but the more well-known ones include the Basement in Manchester; the Cowley Club in Brighton; the London Action Resource Centre (LARC); the Institute for Autonomy and 54A Resource Centre in London; the 1-in-12 Club in Bradford; the Autonomous Centre of Edinburgh; Lancaster Autonomous Resource centre; the Sumac Centre in Nottingham; and the Common Place in Leeds. Many of these centres owe their precarious existence in high cost central areas to wealthy benefactors, the use of central government and lottery finding, and longstanding ethical property owners (such as church groups and the Ethical Property Company). A small group of active volunteers normally run the centre with more occasional membership of several hundred. Each centre's exact focus varies according to the core group's vision; some are more ecological, some more community-oriented, others more connected to punk and anarchist scenes. Crossfertilization with other squatter, traveller and direct action groups exists, as well as a desire to make connections with local struggles in surrounding neighbourhoods, around issues such as policing, asylum and privatisation. Activities vary but normally include affordable food and drink provision in the context of food politics (food miles, veganism, organic), support for grassroots entertainment (film, music, spoken word), media-lab based around independent journalism, meeting space for political groups, and a resource centre with books/magazines. In the Common Place social centre, supported by one of the authors, a desire exists not just to build a physical space but to strengthen common bonds of affinity and understanding. In this sense, while the project has a limited lifespan in any location, its longer significance is the formation of a dense network of social relations based around experimenting with new decisionmaking methods, extended critiques of social and economic relations, and self management of not-for-profit accessible activities including a vegetarian kitchen, cinema, bar, garden, community projects and gig space.

Again, we do not wish to suggest that such spaces are unproblematic or particularly stable. Given that there is no place outside the reach of capitalist relations, 'new places' have to be created from within, through an attempt -- however complicated, contested and fractured -- to alter and challenge everyday places. Within such ventures, many activists have felt compromised due to engagement with legislative requirements, bureaucratic red tape and the wage economy. For example, fire regulations infringements temporarily closed the Common Place in Leeds in 2005. Many alternative, resistant groups are also accused of hypocrisy for selective engagement with wage labour, commerce and consumerism. A recent pamphlet entitled 'You can't rent your way out of a social relationship' discussed how groups who let property to open social centres, as opposed to squatters, are merely reproducing the very values they seek to undermine. Continuing problems of internal hierarchies (of knowledge and competence) and boundaries of inclusion/exclusion exist within social centres. Many participants are acutely aware of outsiders' perceptions - do they appear as ghettos that stop people from participating? Are they really connected to everyday issues? Is it easy for people to come and get involved? 
While no easy answers to these issues exist, addressing them is the bedrock of making autonomy. Interstitial living can also be a source of creativity, producing hybrid, flexible and transient identities, challenging the norms we live by and creating potent new interactions (Hetherington, 1998; Sibley, 1995; Chatterton and Hollands, 2003).

\section{Conclusions}

We have argued for a need to re-examine the practices of activists, specifically in their everyday lives. Autonomy 'opens up' place to broader possibilities, as it is not about 'anchoring' capital to place (Douthwaite, 1996) or creating human-friendly capitalist economies, but about making times and spaces for alternative visions. Thus, unlike an explicit and arguably restrictive focus on the 'local,' it offers the hope of connected and transformatory practices. As DeFilippis (2004) notes, these spaces and practices may be fractured, incomplete and transitory, but if they can improve the lives of participants, they will be better understood and repeated. It is disingenuous to disregard such activities because "no coherent oppositional position has developed, no positive or very convincing alternatives have been formulated" (Cameron and Palan 2004, p.41). To do so ignores such movements' heterogeneity, longevity and creativity and more importantly, it misunderstands participants' aims and practices.

As we have established, autonomy is a contextually- and relationally-grounded concept in specific networks of social struggles and ideas across different times and spaces. Autonomous geographies are not new, and each has its own important history which are increasingly replicated and imbued with new meanings and practices. Autonomous geographies allow us to move beyond the dichotomy of global-bad, local-good. Hence, autonomy can be a tool for understanding how hybrid and interstitial spaces are (re)made and (re)constituted. So what of the concept's utility theoretically and practically? Clearly, autonomy is not a panacea, nor should it become a new blueprint. We have adopted the term autonomous geographies to develop a theoretical vocabulary around urgency, hope and inspiration. It is a plea for us to think our way out of multiple crises, and also a practical call to action. Making autonomy is not easy or unproblematic. Problems within the activist community such as machismo, limited life-spans, disengagement from local communities, illegality, and ghetto and political lifestyles are difficult to shake off. There remain questions as to whether those engaged in autonomy recognise, challenge and overcome such issues. Indeed, are such autonomous spaces merely indicative of the broader societal rejection of difference and the continued search for 'like-minded' communities? The key then is how these autonomous visions become linked and generalisable without recreating exclusions and power concentrations.

Many persistent differences in ideology and strategy exist between those claiming autonomy as a guiding principle, as illustrated by the differences within the contemporary anti-capitalist movement. Those seeking autonomy also face the very real issues of embedded power in many areas of everyday lives. Furthermore, few workable examples exist to be inspired by, an absence that weakens their appeal compared to the relative security of an adaptable capitalist system. It is difficult to sustain loyalty to an autonomous politics which is nothing more than a tendency and may in all likelihood fail. Such visions require an openness of experimentation, an acknowledged contestation and flux which is "an approach toward, a movement beyond set limits into the realm of the not-yet-set" (Brammer, 1991, p.7, emphasis in original). As the poet Antonio Machado said, we make the road by walking. We have 
to become accustomed to uncertainty, which is not a sign of failure as the search is not for meta-theory or new dogmas. Instead, the way forward is through connecting with others who are also experimenting with autonomy, and recovering a collective memory based on past examples largely denied by official channels. The idea of autonomous geographies provides researchers, activists and the public with pieces of a toolkit for ongoing practical and theoretical engagements with building a more socially, environmentally and ethically just future. Moreover they provide hope that 'there are many alternatives'.

\section{Acknowledgements}

We would like to thank Stuart Hodkinson, Angus Cameron, three anonymous reviewers, and participants at the $4^{\text {th }}$ International Critical Geographers Conference in Mexico City, January 2005 for the constructive comments on earlier versions of this paper and all of those worldwide struggling for a more autonomous future.

\section{References}

Anderson, J 2004: The Ties that Bind? Self- and Place-identity in Environmental Direct Action. Ethics, Place and Environment 7 1-2, 45-57

Bauman, Z. 2002: Society Under Siege. Polity Press, Cambridge

Begg, A. 2000: Empowering the Earth: Strategies for Social Change. Green Books, Devon.

Berkman, A. 2003: What is Anarchism? AK Press: London.

Bey, H. 1991: The temporary autonomous zone, ontological anarchy, poetic terrorism. Autonomedia, New York.

Blomley N. 1994: Activism and the academy. Environment and Planning D: Society and Space 12, 383-5.

Blunt, A and Wills, J. 2000: Dissident Geographies. Harlow: Prentice Hall.

Bookchin, M. 1996: Social Anarchism or Lifestyle Anarchism: An Unbridgeable Chasm. AK Press.

Bourdieu, P. 1991: Language and Symbolic Power. Polity Press, Cambridge.

Brammer, A. 1991: Partial Visions: Feminism and Utopianism in the 1970s. Routledge, London.

Brown, M, P. 1992: The Possibility of Local Autonomy Urban Geography, 13 (3) 25779

Butler, C, T and Rothstein, A 1988: On Conflict and Consensus: A Handbook on Formal Consensus Decisionmaking, Food Not Bombs Publishing, online at http://www.consensus.net/

Callinicos, A. 2003: An Anti-Capitalist Manifesto. Polity Press, London.

Carmen, R. 1996: Autonomous development. Zed Books. London.

Cameron, A and Palan, R. 2004: The Imagined Economies of Globalisation. London, Sage.

Castells, M. 1996: The rise of the network society. Oxford: Blackwell.

Castells, M. 1983: The city and the grassroots : a cross-cultural theory of urban social movements. London. Edward Arnold.

Castoriciados, C. 1991: Philosophy, Politics, Autonomy: Essays in Political Philosophy. Oxford University Press, Oxford.

Chatterton, P. 2005: Making autonomous geographies: Argentina's popular uprising and the 'Movimiento de Trabajadores Desocupados' (Unemployed Workers Movement)'. Geoforum, 36, 545-561 
Chatterton, P and Hollands, R. 2003: Urban Nightscapes. Youth cultures, pleasure spaces and corporate power. London: Routledge.

Chatterton, P. 2002: 'Squatting is still legal, necessary and free'. A brief intervention in the corporate city. Antipode 341: 1-7.

Clark, G, L. 1984: A Theory of Local Autonomy. Annals of the Association of American Geographers, 74 2: 195-208.

Cleaver, H. 1979: Reading Capital Politically. Brighton: Harvester

Cleaver, H. 1993: Kropotkin, self-valorization and the crisis of Marxism Anarchist Studies, 2, 2, www.eco.utexas.edu/facstaff/Cleaver/Kropotkin.html.

Cloke, P. 2002: Deliver us from evil? Prospects for living ethically and acting politically in human geography. Progress in Human Geography, 26, 5, 587604

Cockburn, A and St Clair. 2000: Five Days That Shook the World: The Battle for Seattle and Beyond. Verso Books.

Cook, I and Pepper, D eds: 1990: Anarchism and Geography. Contemporary Issues in Geography and Education. 32.

Creswell, T. 1996: In place, out of place. Geography, Ideology and Transgression. Minneapolis. University of Minnesota Press.

Cumbers, A and Routledge, P. 2004: Alternative geographical imaginations. Introduction. Antipode, 818-829.

de Souza, M 2000: Urban development on the basis of autonomy. Ethics, Place and Environment. 32 187-201

de Certeau, M. 1988: The practice of everyday life. Berkeley. University of California Press.

DeFilippis, J. 2004: Unmaking Goliath: Community Control in the Face of Capital Mobility. Routledge, London.

Dirlik, A. 2000: Place-based imagination: Globalism and the politics of place. In A.Dirlik, Places and politics in the age of globalization. Rowman and Littlefield, New York.

Douthwaite, R, J 1996: Short circuit: strengthening local economies for security in an unstable world Devon. Green Books

Duffuor, F and Bové, J. 2001: The world is not for sale. Verso, London.

Escobar, A. 1995: Encountering Development: The Making and Unmaking of the Third World. Princeton, Princeton University Press.

Escobar, A. 2001: Culture sits in places: reflection on globalism and subaltern strategies of localization. Political Geography, 20, 139-174.

Featherstone, D. 2003: Spatialities of transnational resistance to globalization: the maps of grievance of the Inter-Continental Caravan, Transactions of the IBG, 28, 404-421.

Featherstone, D. 2005: Towards the relational construction of militant particularisms: or why the geographies of past struggles matter for resistance to neoliberal globalisation. Antipode, 32, 2, 250-271.

Freire, P. 1979: The politics of education: culture, power, and liberation. Basingstoke: Macmillan.

Fuller, D. 1999: Part of the action, or 'going native'? Learning to cope with the 'politics of integration'. Area, 31, 3, 221-227.

Gibson-Graham, J K. 1996: The End of Capitalism as we knew it, Oxford: Basil Blackwell.

Goodwin J, Jasper J and Polletta F. eds 2001: Passionate Politics. Emotions and Social Movements. Chicago University Press: Chicago

Gordon, N and Chatterton, P. 2004: Taking back control. A journey through Argentina's popular uprising. Leeds: University of Leeds. 
Halfacree, K. 2004: 'I Could Only do Wrong': Academic Research and DIY Culture. In D Fuller and R Kitchin eds Radical Theory/Critical Praxis: Making a Difference Beyond the Academy? Praxis (e)Press. 68-79.

Hardt, M and Negri, A. 2000: Empire. Harvard University Press, London.

Hardt, M and Negri, A. 2005: Multitude. Hamish Hamilton, London

Harvey, D. 2001: Spaces of Capital. Towards a critical Geography. Edinburgh. Edinburgh University Press.

Harvey, D. 2003: The new imperialism. Oxford: Oxford University Press.

Hetherington, K. 1998: Expressions of Identity. Space, Performance, Politics, London: Sage.

Hines, C. 2000: Localisation: A Global Manifesto. London: Earthscan.

Holloway, J. 2002: Change the world without taking power. London: Pluto.

Houtart F and Polet F. 2001: The Other Davos: The Globalization of Resistance to the World Economic System, London: Zed, 7-16.

Indymedia, 2003: On conflict and consensus. The IMC a new model. Indymedia in association with Hedonist Books.

Joll, J. 1979: The Anarchists. London: Methuen.

Jordan, T. 2002: Activism! Direct Action, Hacktivism and the Future of Society. Reaktion Books, London.

Katsiaficas, G. 1997: The Subversion of Politics: European Autonomous Movements and the Decolonisation of Everyday Life. Humanity Books.

Kidd, D. 2003: Indymedia.org: A New Communications Commons. In M.McCaughey and M.Ayers eds.: Cyberactivism: Online activism in theory and practice. Routledge, London.

Kingsnorth, P. 2003: One No, Many Yeses: A Journey to the Heart of the Global Resistance Movement. Free Press: London.

Kitchen, R and Hubbard, P. 1999: Research, action and 'critical' geographies. Area, 314 195-198

Kropotkin, P. 1972: Mutual aid: a factor of evolution. London: Freedom.

Kropotkin, P. 1987: Fields, factories and workshops tomorrow. London: Freedom.

Kumar, K. 1987: Utopia and anti-utopia in modern times. London: Blackwell

Lash, S. 1994: Reflexivity and Its Doubles: Structure, Aesthetics, Community. In U.Beck, A.Giddens and S.Lash eds: Reflexive Modernization: Politics, Tradition and Aesthetics in the Modern Social Order. Polity Press, Cambridge.

Lotinger, S and Marazzi eds. 1980: Italy: Autonomia. Post political politics. Semiotexte:. 3, 3. NewYork, Columbia University.

Mander J. and Goldsmith E eds.: 1996: The case against the global economy: and for a turn toward the local. San Francisco: Sierra Club Books.

Mann, M. 1986: The Sources of Social Power, vol.1. Cambridge University Press, Cambridge.

Marshall, P. 1992: Demanding the impossible. A history of anarchism. London: Harper Collins.

Massey, D. 2004a: Geographies of responsibility. Geografiska Annaler. 86 B 5-18

Massey, D. 2004b: For Space. Sage, London.

McKay, G. 1998: DIY Culture party and protest in nineties' Britain. London: Verso.

Melucci, A. 1996: Challenging codes: Collective action in the information age. Cambridge, Cambridge University Press.

Mertes, T. 2004: The movement of movements. A Reader. Verso: London.

Mouffe, C. 2000: The Democratic Paradox, Verso 
Mouffe, C. 2005: On the Political, Routledge

Mudu, P. 2004: Resisting and challenging neoliberalism: the development of Italian social centres. Antipode. 917-941.

Notes From Nowhere eds.: 2003: We Are Everywhere, the Irresistible Rise of Anti Capitalism. Verso. London.

Oldenburg. 1999: The Great Good Place: Cafes, Coffee Shops, Bookstores, Bars, Hair Salons, and Other Hangouts at the Heart of a Community. Marlowe \& Company

Pain, R. 2003: 'Social geography; On action-oriented research' Progress in Human Geography. 27, 5, 649-657.

Peck, J and Tickell, A. 2002: 'Neoliberalizing Space' Antipode, 34, 3, 380-404.

Pickerill, J. 2003a: Out in the open: Indymedia networks in Australia presented at Information Communication and Society Symposium, Oxford University, September.

Pickerill, J. 2003b: Cyberprotest: Environmental activism online. Manchester University Press.

Pickerill, J. 2004: Rethinking political participation: Experiments in internet activism in Australia and Britain. In R.Gibson, A.Roemmele and S.Ward, Electronic Democracy: Mobilisation, Organisation and Participation via new ICTs. Routledge, London.

Pickerill, J. forthcoming: Autonomy on-line: Indymedia and practices of alterglobalisation. Environment and Planning $A$.

Pile, S and Keith, M. eds.: 1997: Geographies of Resistance. London: Routledge.

Pinder, D. 2002: In defence of utopian urbanism: Imagining cities after the 'end of utopia'. Geografiska Annaler, 84B 229-241.

Plows, A. 2002: Praxis and Practice: The 'What, How and Why' of the UK Environmental Direct Action EDA: Movement in the 1990's. Unpublished thesis. Department of Sociology, University of Wales.

Proctor, J. 1998: Ethics in geography: giving moral form to the geographical imagination. Area. 301 8-18.

Purkis, J. 1996: Daring to dream: idealism in the philosophy, organisation and campaigning strategies of Earth First!. In C. Barker and P. Kennedy, To Make Another World: Studies in protest and collective action. Aldershot, Avebury: 197-215.

Reynolds, H. 1989: Dispossession: Black Australians and white invaders. Allen and Unwin.

Routledge, P. 1996: The Third Space as Critical Engagement. Antipode 284 399419

Routledge, P. 2003: Convergence Space: process geographies of grassroots globalisation networks. Transactions of the Institute of British Geographers, 28, 3, 333-349.

Ruggie, J, G. 2004: Reconstituting the global public domain - Issues, actors, and practices. European Journal of International Relations 10(4): 499-531

Ruggiero, V. 2000: New social movements and the 'centri sociali' in Milan. The Sociological Review, 167-185.

Rupert, M. 2003: Globalising common sense: a Marxian-Gramscian (re-)vision of the politics of governance/resistance. Review of International Studies, 29, 181-198

Sayer, A and Storper, M. 1997: Ethics unbound: for a normative turn in social theory. Environment and Planning D: Society and Space. 15. 1-17.

Schalit, J ed.: 2002: The Anti-capitalism Reader: Anti-market Politics in Theory and Practice, Past, Present and Future. Akashic Press. 
Schumacher, I. 1972: Small is beautiful. Penguin: London.

Seeds for Change. 2003: Consensus decision making, Seeds for Change. On line @ www.seedsforchnage.org.uk

Seel, B, Paterson. M and Doherty, B eds.: 2000: Direct action in British environmentalism. London. Routledge.

Sen, J, Anand, A, Escobar, A, Waterman, P. 2004: World Social Forum: Challenging Empires. New Delhi : Viveka Foundation,

Sharp, J. Routledge, P. Philo, C. Paddison, R eds.: 2000: Entanglements of Power: Geographies of Domination and Resistance. London: Routledge.

Sheehan, S M. 2003: Anarchism. London. Reaktion Books.

Sibley, D. 1995: Geographies Of Exclusion. London: Routledge.

Smith, D. 1994: Geography and social justice. Oxford: Blackwell.

Solnit, R. 2004: Hope in the dark. Nation Books: New York.

Starhawk, 1988: Truth or dare: encounters with power, authority, and mystery. San Francisco, Harper.

Starr, A and Adams, J. 2003: Anti-globalization: The Global Fight for Local Autonomy. New Political Science, 25, 1, 19-42.

Swyngedouw, E. 1997: Neither global; nor local: Glocalisation and the politics of scale. In K.Cox Spaces of globalisation: Reasserting the power of the local. London.

Tarrow, S. 1998: Power in Movement: Social movements and Contentious Politics. Cambridge University Press, Cambridge.

Thrift, H. 1998: 'Soft capitalism' in A.Herod, G.Tuathail and S.Roberts, An Unruly World: Globalization, Governance and Geography. Routledge, London.

Tormey, S. 2004: A beginners guide to anti-capitalism. Oneworld, Oxford.

Vaneigem, R. 1979: Revolution of everyday life. London: Rising Free Collective.

Wall, D. 1999: Earth First! and the anti-roads movement: radical environmentalism and comparative social movements London: Routledge.

Ward, C. 1989: Welcome thinner city. Urban survival in the 1990s. London: Bedford Square.

Wolman, $\mathrm{H}$ and Goldsmith, M. 1980: 'Local Autonomy as a Meaningful Analytic Concept' Urban Affairs Quarterly, 26 1, 3-27

Wright, S. 2002: Storming Heaven: Class Composition and Struggle in Italian Autonomist Marxism. Pluto Press, London.

Yunupingu, G, ed. 1997: Our Land is Our Life. University of Queensland Press, Brisbane. 